\title{
The Catch-22 in Strategizing for Radical Innovation
}

\author{
Helle Alsted Søndergaard, Mette Præst Knudsen, \& \\ Nicolai Søndergaard Laugesen
}

\author{
" The enterprise that does not innovate ages and declines. And in a period of rapid change such \\ as the present, the decline will be fast. "'
}

Peter Drucker

\begin{abstract}
Corporate strategy development is a well-oiled and recurring process in most established companies. Innovation strategy, however, especially for radical innovation, is new and unknown territory. This creates challenges for companies with radical innovation ambitions. We followed the innovation strategy work of nine large organisations, finding that they all struggle with the process and how to link innovation with corporate strategy in a meaningful way, while at the same time not hampering the innovative ambitions of the organisation. We identify two main challenges of gravitation and alignment, and develop a framework aimed at asking the questions necessary for increasing awareness about inherent business challenges, and how to overcome them at the intersection between corporate and innovation strategy work.
\end{abstract}

\section{Introduction}

Strategy concerns explaining what enables firms to enjoy sustainable performance advantages over their competitors. The pressure to innovate nowadays is higher than ever, while companies struggle to focus on identifying and targeting the right opportunities to pursue continued competitive advantages. While adequate resources, the right people, an open innovation process, and effective market orientation have been stressed as core elements for successfully pursuing innovation opportunities (Barney, 1991; Sirmon et al., 2011; Carnes et al., 2017), less attention has been given to innovation strategy. As innovation is a key driver of a firm's performance advantages, it becomes natural to ask how strategies can be formulated and implemented to drive innovation. The ambition to innovate with radical new offerings for the market can be especially challenging (Hill \& Rothaermel, 2003; O'Connor \& DeMartino, 2006; Sainio et al., 2012). This article addresses the challenges by proposing a framework for formulating a radical innovation strategy.
Corporate strategy serves as an indispensable tool for management to ensure direction for the entire organization (Feldman, 2020). It is less clear, however, what specifically shapes an innovation strategy, what its boundaries are, and how often it is to be adjusted or reshaped. As innovation orients towards capturing future opportunities, which continuously change in multiple possible directions, we find it worth considering what can and cannot be captured with existing strategy tools.

This article explores the relationship and differences between corporate strategy and innovation strategy, especially when radical innovation is being strategized. Our main argument is that the severity of the uncertainties associated with radical innovation necessitate an approach to innovation strategy which is based on a managerial mindset that not only accepts, but embraces these inherent uncertainties. This fundamentally differs from the well-established and widely-shared corporate strategy approach (Kuratko et al., 2014). We thus argue that existing corporate strategy tools actually impair a company's chances of succeeding with radical innovation. 


\title{
The Catch-22 in Strategizing for Radical Innovation
}

\author{
Helle Alsted Søndergaard, Mette Prost Knudsen, \& Nicolai Søndergaard Laugesen
}

Corporate strategy develops based on a well-known and familiar set of tools used by top management. It aims to provide direction for the organization and guides a company's current efforts and corporate activities. At the same time, corporate strategy involves a series of transactions as opposed to single events, and hence strategy unfolds dynamically across time, rather than as a mythical single strategic plan (Feldman, 2020). Managers may find an innovation strategy hard to understand especially if it targets radical innovation, involving how the strategy ensures that innovation activities are turned into value for future competitiveness, and how it relates to corporate strategy.

In a study of nine large Danish firms that we conducted, we found that they all experienced difficulties in crafting a radical innovation strategy. They had years of experience and go-to tools for their corporate strategy work, while radical innovation strategy, for them, was outside of their normal playing field of strategic work. They experienced two main challenges, and in their efforts to deal with these challenges, they ended up finding themselves in a catch-22: if they ignored one challenge, they ended up facing another. In response to this dilemma, we contribute to the innovation management literature by offering a framework that addresses the central questions firms tend to forget when crafting radical innovation initiatives. The framework's aim is to help alleviate this catch-22 of strategizing for radical innovation.

\section{Theoretical Framework}

We start with a basic definition of "strategy". A strategy is nothing more than a commitment to a pattern of behavior intended to help win a competition (Pisano, 2012). When developing corporate strategy, managers therefore have a fairly straight-forward task to formulate plans that drive the organization with focus on efficiency and long-term goals. Feldman (2020) identifies the core question for corporate strategy as what enables firms to enjoy sustainable performance advantages over their competitors. Hence, corporate strategy formulates a commitment to the best possible path for obtaining a desired performance advantage. Pisano (2012) argues for three core principles of a good strategy: consistency, coherence, and alignment. One path for realizing these strategic principles may be through cost optimization and lean management, while another may be through proactive innovative efforts ideally resulting in pre-emptive radical innovation. As the achievement of future performance is not based on one single decision, a good overall strategy rests on a complex web of decisions and possibilities in continual flux.

We see "innovation" as a multi-faced concept that covers $\mathrm{R} \& \mathrm{D}$ and technology development, and ultimately results in new products and services introduced in the market. It is sprinkled with uncertainty, clouded by conflicting opportunities, driven by the unknown; and rests on desires more than knowledge. However, when innovation becomes a core driver to achieve higher future performance, concern involving the need for a strategy of innovative efforts results.

If corporate strategy is connected with efforts towards formulating innovation strategies, then we observe that corporate strategy works well as a guiding tool to directly promote incremental innovation. The principles of coherence and consistency align well to exploitation, which includes such things as: refinement, choice, production, efficiency, selection, implementation, and execution (March, 1991). Hence, strategy formulation focuses on managing the current business, and "doing what we do today, but better" (Tidd \& Bessant, 2018). Pisano (2015) supports this, noting the importance of alignment between the business core and the innovation strategy. A clearly articulated innovation strategy must therefore be "closely linked to a company's business strategy and core value proposition. Without such a strategy, most initiatives aimed at boosting a firm' capacity to innovate are doomed to fail" (Pisano, 2015).

On the other hand, we cannot overlook March's second dimension of exploration, which he helpfully explains, includes things captured by terms such as: search, variation, risk taking, experimentation, play, flexibility, discovery, and innovation (March 1991). This translates into radical innovation. We know from the literature that radical innovation is difficult for established companies (Hill \& Rothaermel, 2003), while at the same time the fascination with exploration and radical innovation remains strong. As mentioned by Wilden et. al. (2018), "exploration is being mentioned most frequently ahead of exploitation and ambidexterity" in the extant literature, and successful exploration leads to searches 


\section{The Catch-22 in Strategizing for Radical Innovation}

\section{Helle Alsted Søndergaard, Mette Prøest Knudsen, \& Nicolai Søndergaard Laugesen}

outside the familiar competencies and markets. Linton (2009) describes two key dimensions for radical innovation: a significant leap in technological development, and a potential for entirely new features and improvements. In many studies, this has led to the formulation of products that are new to the world. Consequently, the capability to make radical innovation can be regarded as a firm's ability to explore, adapt, tolerate, and experiment with new products, processes and services for non-mainstream businesses (Chang et al., 2012).

Even though corporate strategy addresses expectations for a firm's long-term future business opportunities, it remains unclear on which new technologies or products such opportunities are or should be based, and how these are to be realized through radical innovation, that is, "doing things differently" (Tidd \& Bessant, 2018). The core observation is therefore that corporate strategy cannot and does not act as a "light house" for radical innovation work. This means management can either navigate locally within their own business units to search for ideas and opportunities or leave the radical innovative agenda untouched. This indicates the huge difference in current strategic frameworks for corporate strategy and radical innovation strategy, which potentially constitutes an enormous challenge for companies when they attempt to align radical innovation strategy with corporate strategy for future long-term opportunity capture (Demir, 2018; Dobni \& Sand, 2018). In this paper, we thus aim to explore and shed light on how companies are currently experiencing and managing the paradox of developing innovation strategies for radical innovation.

\section{Methods}

This article is based on interviews with nine large companies across a range of industries. All the companies have international activities and vary in size, three companies from logistics, facility management and finance have yearly global revenues of more than 10 billion EUR, while six companies from transportation, insurance, healthcare, facility management, pharmaceuticals and waste management have yearly revenues from 1-10 billion EUR.

The research focused on the challenges companies face when aligning corporate strategy and innovation strategy, and how to establish alignment between these. Interviews were conducted in 2017 and all company respondents were high-ranking, with detailed insights into the companies' strategic processes, primarily Vice Presidents, Heads of Strategy and Directors of business units. The interviews were semi-structured with focal themes on corporate strategy process and radical innovation strategy. The first part of the interview focused on company corporate strategy, both the strategy process and context, including competitors, turn around, growth, etc. The second part of the interview focused on three themes regarding radical innovation strategy: the company's strategic process, the elements of the radical innovation strategy, and how their strategies in reality are carried out.

As strategic alignment is a relatively unexplored subject, we based the analytical design on an explorative methodological approach. The analysis was separated into two consecutive steps. The first step distilled the companies' strategic approaches and characterized their radical innovation strategies, and how they were integrated into corporate strategy. In the second step, the information collected from the interviews was coded, categorized, and thematized. The analytical process revealed the companies' central challenges related to corporate strategy and radical innovation strategy.

\section{Findings}

While corporate strategy is well-known and based on a familiar set of tools for top management, the vignette and quotes below show it is much less evident for top management what an innovation strategy is, especially if it targets "radical innovation". We found that successful innovation was achieved when a company's strategy ensured that innovation activities got turned into value for future competitiveness.

"The questions that companies ask when developing corporate strategy are well-known to all, but questions for the innovation strategy are not wellknown, if known at all" (Head of Strategy).

"Agility and high intensity are really central for the way we work with innovation, but this has nothing to do with the typical McKinsey-strategy questions; questions that are well-known and often used in the 


\section{The Catch-22 in Strategizing for Radical Innovation}

\section{Helle Alsted Søndergaard, Mette Proest Knudsen, \& Nicolai Søndergaard Laugesen}

strategy process. But when working with innovation we don't know what the questions are before we get started" (Vice President, X-lab)

\section{Vignette on challenges of radical innovation strategy work}

The deadline was approaching, but the innovation strategy was still a big question mark. Before the upcoming board meeting, Mary, Head of Strategy was given the task of crafting an innovation strategy that could mitigate the fast-changing business environment. The company concern was all about disruption, radical innovation, how new competitors were popping up, and markets constantly changing, disappearing, and developing at the same time. The company had seen its market share dwindle, and even though the product portfolio had been updated over the years, the company was losing its position. Mary was commissioned to craft an innovation strategy to be presented at the board meeting and the mandate was clear: an innovation strategy was needed that could secure long term growth and keep the company in front of competitors by means of radical innovation. The question, however, was how to craft a radical innovation strategy?

Mary had in previous strategy development processes reached out to the business units closest to the customers, which provided input that all pointed towards solutions for the current market - and some of these ideas were already being provided by new and agile competitors. Would these inputs give the company the competitive edge that she was mandated to craft an innovation strategy for? This was, more or less, what the company had always done, but she was well aware that radical innovation was needed this time. If the company needed radical change what could it be? Mary had spent a decade working with strategy and she had never felt shorter of answers from her strategy toolbox than with this task. How could she define the potential markets if she didn't even know what the product was? A product that was expected to move the company ahead of competition - a radical new offering - unlike the offerings of the current business units. How to nail a strategy for a fast moving and elusive target; a target yet to be imagined? What were the core challenges she needed to identify and address? (Inspired by real events)
The lack of familiar questions and common vocabulary for innovation strategy are apparent across the case companies studied. They explained that for developing a corporate strategy, they have a common understanding of what it is, what it looks like, and of the process for crafting the strategy. But for a radical innovation strategy, the companies do not have the same grounded experience and understanding, but rather grope in the dark.

"With strategy, we have a fundamental understanding of how the process should be run and we may even have 100 years reflection to lean on. But with innovation and disruption, which have appeared only within the last 4-5 years, no one has a clear idea of what the strategy should look like. That's why it's so difficult to connect the two" (Vice President, Head of Innovation).

\section{Two Central Radical Innovation Challenges Identified}

Apart from the lack of tools and experience discussed above, we observed two main recurring challenges experienced in the companies as they strive to develop and formulate strategies for radical innovation. The mechanisms built into these challenges imply that any attempt to align corporate and radical innovation strategy is at best very difficult and will inevitably drive down the realization of ambitions formulated in the radical innovation strategy. These are the central dynamics of the catch-22 when strategizing for radical innovation.

\section{Challenge 1: Alignment kills strategy work processes for radical innovation}

The complexity of large organizations has been known to hinder efforts to coordinate and align their activities and strategy. This may also be the case for aligning radical innovation strategy with corporate strategy. One consequence of complexity is that it leads to two parallel strategy processes that are out of sync. Although different strategy cycles can be considered as just another challenge to be solved in large and sometimes bureaucratic organizations, most companies struggle with synchronization. The corporate strategy process typically follows the same flow, with minor updates of the strategy from the previous year, while the strategy is more thoroughly revised only every 3 to 5 years (Wessel, 2012). This process secures continuity and coherence of strategic goals and respects the fact that implementing strategic goals in large international organizations takes 


\section{The Catch-22 in Strategizing for Radical Innovation}

\section{Helle Alsted Søndergaard, Mette Prøest Knudsen, \& Nicolai Søndergaard Laugesen}

time to cascade and work, like changing ERP-systems for strengthened operational efficiency or building up a new sales organization to address new markets. In this way, continuity is required in large companies. Hence, large change projects will fail if major new strategic revisions are rolled out every year. Radical innovation strategies, on the other hand, need to capture and address exactly those uncertainties that are foundational when working with radical innovation; a process that is by definition earmarked with trial and error. If everything in the radical innovation process is known from the beginning, the outcome can hardly be expected to be either novel or radical.

Radical innovation is a much messier and emergent set of processes compared with other corporate processes, such as supply chain management or financial operations. Although companies have developed and implemented stage-gate models for guiding innovation activities, these models do not deal with uncertainties at the strategic level. The front end of stage-gate models usually includes detailed templates for business cases, which are applied when assessing the value of new innovation opportunities before they can be turned into projects. These models and templates do not promote radical innovation. For this purpose, companies alternatively implement $\mathrm{x}$-labs that are high-risk endeavours for seeking radical innovation. One risk of implementing $\mathrm{x}$-labs is that business cases typically overestimate the market size and underestimate required time and costs.

Innovation textbooks advocate for a fit between corporate strategy and radical innovation strategy. However, current frameworks for innovation strategy are unable to handle the uncertainties of radical innovation, and stage-gate models are not created to tackle these uncertainties. When the innovation strategy is squeezed to fit into the typical short-term incremental framework of corporate strategy, some companies see no other option than to accept friction, that is, little or no alignment with current corporate strategy. The case companies would rather accept friction than to promote an overly structured approach and too closely align innovation strategy to corporate strategy, which it was believed would ultimately suppress radical innovation efforts.

\section{"We have a clearly defined threat from being} disrupted and it is on the top of our strategic agenda - but our strategic response differs from our
intention" (Director, Operational Development).

In brief, the core challenge for firms was to isolate or distance their radical innovation strategy in order to avoid getting it caught in the cross-fire of short-term corporate strategy and long-term innovation horizons. Their requirement is to deliver business value, before their competitors disrupt the market. Indeed, this forms a challenging set of corporate dynamics to bring together. The central questions are: What happens if corporate and innovation strategy are not aligned and radical innovation strategy becomes decoupled from corporate strategy? And how can managers align corporate strategy and innovation strategy work without jeopardizing the company's radical innovation ambitions?

\section{Challenge 2: Gravitation kills radical innovation strategy ambitions}

Radical innovation is difficult to achieve, impossible to predict and schedule for, and especially so when existing business units are the immediate "customers" of these innovations.

"Our claim to fame is radical innovation, but the only things, we can transfer to the business, are innovations that are ready for the market and just minor adjustments to our current products" (Vice president, $X$-lab).

The organizational reality in the quote is clear. If the innovation lab wants to succeed and prevail, it must show, within a short time-frame, results that even depend on the willingness of the business units as the receiving end in the organization to adopt the innovation. Thus, it must accept an innovation that may directly outcompete its existing offerings.

The trouble is that independent innovation labs are founded on an ambition to present radically new offerings and these take (an uncertain amount of) time and money to achieve. However, if the success of the lab depends not directly on the lab's ability to produce radical innovation, but rather on the business units' accepting the innovation outcomes, then this creates a fundamental paradox. The radicality of the new offering itself may be counter-productive to its actual adoption by the business unit. On the one hand, new products and services should, at some point, be accepted and 


\section{The Catch-22 in Strategizing for Radical Innovation}

\section{Helle Alsted Søndergaard, Mette Proest Knudsen, \& Nicolai Søndergaard Laugesen}

"owned" by the business units, and at the same time, the radical innovation should create offerings that aim to bring the business substantially forward (or even disrupt the market). This will often challenge the existing offerings of the business unit and in this way, radical innovation becomes mission impossible! Thus, even when a company's innovation strategy focuses on long-term radical innovation followed by organizational initiatives, the demand for short-term gains or products that fit with the existing business model will challenge efforts to plan and achieve a radical innovation strategy.

Even when the strategic ambition for radical innovation is set and pursued, an organization may (over time) get impatient and start to question the (lack of) progress and results. The innovation lab managers will then be inclined (or pressured) to present innovations of a more incremental and predictable nature as a way to prevail against and overcome the pressures for short-term gains at the cost of potential future radical innovation.

If, on the other hand, the innovation lab does manage to produce and present radical innovations, these are then often challenged by the business units themselves, as radical innovations are unlikely to be in accordance with current business units' perceptions of market needs. Hence, when radical innovation is achieved, it is likely that it will be dismissed and seen as "a cuckoo in the bird's nest", a certain path to blocking the innovation. It is not only a matter of asymmetric powers in the organization, it is also a matter of asymmetric knowledge where corporate innovation labs are experts in future trends, technology, and innovation methodologies, whereas the business units have first-hand knowledge of current customers and markets. The incremental innovation strategy and the short-term businessoriented approach is not a problem per se, rather the problem occurs when the strategic intent is initially more radical, but instead ends up being altered because of an asymmetric power relation between the business units and the innovation lab. In such cases, the radical innovation strategy gets challenged by short term strategic goals that contradict and even prevent the radical innovation strategy from being realized.

To summarize, even when companies formulate breakthrough innovation strategies, they may end up only with incremental outcomes. The business units in large organizations exercise a strong pressure through their operational needs, which gravitates the power from headquarters to the decentralized local level in such a way that business unit interpretations alter the innovation strategy to a more comprehensible shortterm market-focused strategy. This strategic focus is distinct from the long-term radical innovation strategy that the corporate level stimulates and pursues. The gravitation therefore shifts attention away from any radical innovations towards incremental innovation, which can more readily be adopted.

The two challenges demonstrate that even though a radical innovation strategy states one ambition, implementation of the strategy (often) takes a very different route, and a route that diverts attention more towards achieving incremental innovation. To enable long-term strategic gains from innovation, the innovation strategy process requires more risk willingness (in the business units), acceptance of extended time that may be needed to realize the gains, and recognition in the organization that gains cannot accurately be predicted in business plans prior to engaging in an innovation process for radical innovation. Again, while this may and often does seem paradoxical, it also appears to be the only way to get the business of radical innovation done.

Various organizational approaches can be applied by companies as a way of attempting to secure radical innovation. While some have integrated this work in the business development function or formed internal cross-functional units, others have created independent and separate innovation labs or established spin-off business units (O'Connor \& DeMartino, 2006). A popular current way to seek a radical outcome is by organizing part of the strategic efforts in physically separated external organizational units like x-labs. Others again choose to be "fast followers". Here is how one company formulates the strategy:

"The choices are too many and the uncertainty too high - so where to place the bet? We don't know and instead we choose to follow the trends in the market" (Director, Operational Development).

Interestingly, in this company, the board originally aimed for a blue ocean strategy, but the innovation department ended up with a much more incremental 


\section{The Catch-22 in Strategizing for Radical Innovation}

\section{Helle Alsted Søndergaard, Mette Prøest Knudsen, \& Nicolai Søndergaard Laugesen}

maneuver, because they did not have the tools to handle the uncertainties associated with a radical innovation strategy.

Zooming in on the different ways of organizing for radical innovation, companies with separate innovation units usually have intentionally formulated more radical and long-term oriented strategies, in order to avoid the gravitation challenge. However, they then face stronger challenges in aligning corporate and innovation strategies. These conflicting forces represent a built-in catch 22 for strategizing and realizing radical innovation. If a company strategizes to pursue radical innovation, it must first secure the freedom to deviate from current corporate strategies. Hence, we acknowledge that while a certain level of coordination between corporate and innovation strategy is needed, if a firm aims for radical innovation, management must also accept that the two cannot be fully aligned.

\section{Development and Discussion of a Strategy Framework}

Radical innovation is about developing new solutions for new business opportunities, rather than responding to already recognized opportunities (Kim \& Mauborgne, 2019). Hence, the formulation of a radical innovation strategy must address different questions than those used for guiding the development of corporate strategy. The premise for the radical innovation strategy is very different from that of typical corporate strategy, as the former concerns how the company handles unknown questions about the future while the latter is about securing immediate and realizable growth opportunities. Radical innovation involves experimentation and testing of multiple paths to the market and these uncertainties must be accepted as part of the strategy process. Hence, it also requires other additional key strategic questions.

Based on our understanding of the challenges experienced and how innovative efforts are carried out in the companies studied, we were able define two central questions linked to radical innovation strategy work that we believe need to be addressed: what level of ambition is its aim? What is the search direction? The level of ambition translates into the degree of (potential) radical innovation, while the direction means the proposed or conceptualized business opportunities, markets, or technologies to search for.

\section{How radical do we want to go? \\ Key question: What is the desired level of novelty of our radical innovation efforts?}

As innovation is by definition characterized by uncertainty and ambiguity, the level of ambition also embraces the level of uncertainty. Considering the level of ambition in a radical innovation strategy creates a way to embrace the expected level of uncertainty, but also to manage the potential gravitation towards incremental uncertainty. Maintaining focus on the ambition is crucial for avoiding the gravitation challenge.

\section{Case 1: Facility management company}

In Company $\mathrm{A}$, the starting point was to establish a corporate garage and then let possible themes for innovation emerge by collecting input from customers and business units. The corporate garage was established to develop radical innovation, whereas incremental innovation was the responsibility of the business units. In this way, the level of ambition was chosen before the direction.

When the starting point was the innovation ambition, and in this case had a clearly defined strategic objective of radical innovation, the firm faced the challenge of possible misalignment with the corporate strategy. That is, if the corporate garage were to explore other directions than what the corporate strategy defined, this ultimately would cause friction unless the corporate strategy was explicitly open for exploration.

For the corporate garage or $\mathrm{x}$-lab to succeed or even survive, it was equally important that the long-term time-horizon for the radical innovation be well-known because radical innovation takes time. It can be tempting to show results by presenting new, but only incremental innovations to the business units. One solution, as described above, is to link the level of ambition with an innovation direction that resonates with corporate strategy, but still keep the level of ambition intact.

The level of a company's ambition thus describes how far away from the current position the company wants to explore new territory (Anthony et al., 2008; Nagji \& Tuff, 2012; Pisano, 2015). The typical way to describe level of ambition is using the radical versus incremental. The 


\section{The Catch-22 in Strategizing for Radical Innovation}

\section{Helle Alsted Søndergaard, Mette Proest Knudsen, \& Nicolai Søndergaard Laugesen}

more radical, the higher the level of ambition required, whereas incremental reflects a lower level based on achieving minor changes to current products or solutions. Despite being formulated explicitly as "radical innovation", efforts may be in continuous danger of being pushed towards innovation that resonates with the current position or business model (see Challenge 2: Gravitation kills radical strategy ambitions). In the literature on managing innovation portfolios, the level of ambition is a question of choosing how to distribute investments into, for example, current core offerings, adjacent opportunities, or new territory (Nagji \& Tuff, 2012). This is illustrated by how new and unknown the products and markets are compared to existing offerings.

\section{Where do we want to go radical?}

Key question: Where do we want to focus our radical innovation efforts?

The second dimension provides the direction of innovation efforts and points to areas in which the company chooses to innovate. The strategic question for this dimension starts with the current position and compares this to the coordinated direction in which the efforts will or should take place for market, product or technology, and whether it is related to, for example, the business model or process innovation (Sawhney et al., 2006; Tidd \& Bessant, 2018).

\section{Case 2: Logistics company}

Company B has initiated a long-term radical innovation strategy. The innovation strategy is focused to build on their core business of container transportation. This entails first choosing a direction and then defining the innovation ambition. In this case, the company chose radical innovation within container transportation with a long-term horizon. The path is thus defined by starting with the innovation direction and Company B clearly has a strategic advantage in knowing the product and market that are subject to innovation. But this directional path also has the embedded risk of gravitating towards incremental innovation.

When the direction involves the core products and market of the company, then the innovation effort will ultimately challenge the current business. This means that prioritizing corporate strategy vis-à-vis radical innovation must be sustainable. Alternatively, the firm may risk facing both challenge 1 and 2 .

Some companies choose to innovate around their core products or services, limiting the possible radical innovation directions to take. Another choice is to deliberately search in totally new growth areas, letting the direction be driven, for example, by an emerging technology. Whenever new technologies, such as 3Dprinting, augmented reality, or any other fast-growing opportunity from the plethora of technologies that surround us, become available for exploration, some companies choose to engage with these technologies to identify if, and how, the technology can support their existing business, or become a viable new part of the company. In this case, exploration means that it is yet to be established if the technology will be applied to existing or new markets, or whether it holds any commercial value.

Direction is not only a question of product and technology, but can also be related to customer and market. Instead of starting with new technology, some companies start with the customer and via customer journeys and observations, try to distill unidentified needs that they can innovate to meet (Brown \& Martin, 2015). In this way, the solution and technology are yet to be defined, but the company has to some extent narrowed down customer needs for the market segment. Each dimension represents different perspectives for strategy, including search direction, level of ambition, timeline, and alignment, all of which have strategic choices embedded. These dimensions seem to only make a coherent strategy when considered in concert, and thus choices across the dimensions must be considered together, as they may otherwise contradict each other.

Looking back at this paper, we have added to the existing literature by illustrating a paradox involving strategy work when it comes to crafting a radical innovation strategy while juggling it alongside corporate strategy. We identified two recurrent challenges of alignment and gravitation and showed how they form a catch-22 for companies as they are intertwined and interlinked. Core trade-offs, important choices, and questions have been already mentioned in the literature, some of which were highlighted here (Shawney et al 2006; Nagji \& Tuff, 2012; Pisano, 2015; Tidd \& Bessant, 2018). The novelty of this research lies in the clearer formulation of a paradox, 


\section{The Catch-22 in Strategizing for Radical Innovation}

\section{Helle Alsted Søndergaard, Mette Proest Knudsen, \& Nicolai Søndergaard Laugesen}

based on the underlying dynamics of strategies as they are developed and particularly implemented, leading companies into catch-22s.

Hence, the ambition to strategize for radical innovation requires much more than only a corporate strategy or "new awareness", and especially more than just the three principles of coherence, consistency, and alignment (Pisano, 2012). In fact, it is our conclusion that these principles are or at least can be counterproductive towards succeeding with radical innovation. In the research we conducted, the principles became strong fences that prevented radical innovation from being targeted and developed. Hence, we were surprised by finding how easily radical innovation strategy can lose its feet when confronted with strongly established corporate strategy practices. Rather than being a guidepost, corporate strategy has the potential to become a straight-jacket for radical innovation efforts in that it can prevent the capabilities for radical innovation from securing adequate innovation performance, and thus ultimately interfere with or impede long-term sustainable growth.

In response to this, we propose below a managerial framework. The elements of this framework are not in themselves new, but we added the overlooked challenges and dynamics identified in the research above to enhance the chances of successful corporate strategic work. We believe that this contribution is important for innovation scholars and managers as it challenges pre-existing conceptions and notions about how innovation strategy is specifically related to, and should take its point of departure from corporate strategy (Pisano, 2015).

\section{A Managerial Framework}

As shown above, the premise for a radical innovation strategy, as experienced by the companies in this study, is very different from that of a corporate strategy. Innovation strategy work is currently, in practice, based on strategy approaches that do not recognize the contradiction between these two different strategies. We therefore propose a framework that recognizes the contradictions and accompanying uncertainties. We base the framework for making a radical innovation strategy on evidence from the companies studied in our research, coupled with central concepts from management theory, such as exploration and exploitation (March, 1991), along with more recent managerially-inspired strategy frameworks (Sawhney et al., 2006; Pisano, 2015; Dobni \& Sand, 2018; Prange \& Schlegelmilch, 2018).

Through consideration of the identified two main challenges and two central questions, as well as their underlying decisions, a radical innovation strategy should connect the company's innovation ambition with their innovation direction. To avoid the pressures exerted by current business logic and corporate strategy, radical innovation strategy should focus on the strategic choices of both ambition and direction. Current attempts at creating innovation strategies
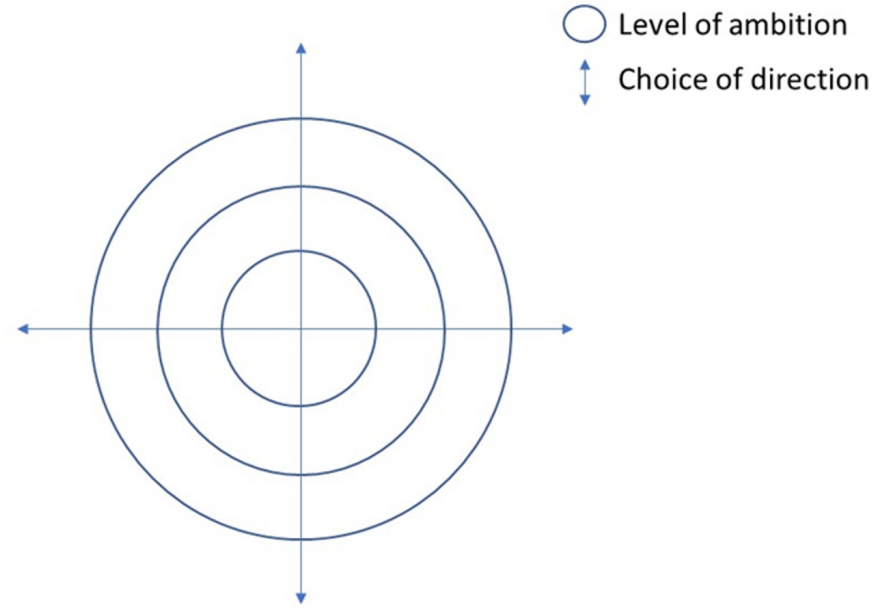

Figure 1. Innovation ambition and direction in conjunction 


\section{The Catch-22 in Strategizing for Radical Innovation \\ Helle Alsted Søndergaard, Mette Proest Knudsen, \& Nicolai Søndergaard Laugesen}

often focus on one of the dimensions in isolation or do not even specify the dimensions that the innovation strategy should work on. Yet a chosen focus on a new technology, for example, is not in itself a coherent innovation strategy and other additional choices need to be made (Prange \& Schlegelmilch, 2018). Figure 1 shows a stylized illustration of how the two central dimensions of ambition and direction have also been interlinked in the current literature (Shawney et al 2006; Tidd \& Bessant, 2018).

The centre of figure 1 illustrates the current offerings, abilities of the firm, its competencies, human resources, technologies, and other endowments. The search space for new innovative opportunities are then defined around this core. The closer the firm searches around its core, the more likely it is that the firm's innovation activities will result in incremental innovation. Radical innovation strategies should consist of a combination of ambition (for example, new product in new business area) and direction (for example, identifying new ways of utilizing a specific technology in the firms' products). The innovation strategy can have the starting point or offset in either of the two dimensions described. If the offset is a direction, then the company identifies the product,

Table 1. Designing your Radical Innovation Strategy

\begin{tabular}{|c|c|c|}
\hline & $\begin{array}{c}\text { Level of innovation } \\
\text { ambition }\end{array}$ & $\begin{array}{c}\text { Choice of innovation } \\
\text { direction }\end{array}$ \\
\hline $\begin{array}{c}\text { Step 1: Asking the right } \\
\text { questions }\end{array}$ & $\begin{array}{l}\text { What is the desired level of } \\
\text { novelty of our innovation } \\
\text { efforts? } \\
\text {-How high is our ambition? } \\
\text {-How far is our aim from our } \\
\text { current position, } \\
\text { competences, knowledge? }\end{array}$ & $\begin{array}{l}\text { Where do we want to focus } \\
\text { our innovation efforts? } \\
\text {-Which direction(s) do we } \\
\text { aim to take? } \\
\text { - adjacent to existing product } \\
\text { or market, or new territory? } \\
\text {-Do we have the right } \\
\text { competences for the } \\
\text { directions chosen? }\end{array}$ \\
\hline $\begin{array}{l}\text { Step 2: Understanding the } \\
\text { gravitational forces }\end{array}$ & $\begin{array}{l}\text { Current position and market } \\
\text { (customer) needs draw } \\
\text { innovation efforts towards } \\
\text { achievable outcomes. Hence, } \\
\text { the level of ambition is } \\
\text { constantly in danger of being } \\
\text { lowered. }\end{array}$ & $\begin{array}{l}\text { Current corporate strategy } \\
\text { departs from existing } \\
\text { business areas and offerings: } \\
\text { it will draw company efforts } \\
\text { in (a) known direction(s). }\end{array}$ \\
\hline $\begin{array}{l}\text { Step 3: Challenging the } \\
\text { degree of alignment }\end{array}$ & $\begin{array}{l}\text { Since current corporate } \\
\text { strategy tools prescribe } \\
\text { known outcomes and } \\
\text { achievable targets, this can } \\
\text { lower the innovation } \\
\text { ambition. } \\
\text { A radical innovation } \\
\text { ambition requires deviation } \\
\text { from the corporate strategy. }\end{array}$ & $\begin{array}{l}\text { If the chosen innovation } \\
\text { direction leads efforts } \\
\text { towards entirely new } \\
\text { technology or platform } \\
\text { opportunities, the current } \\
\text { business model may try to } \\
\text { ensure that the innovative } \\
\text { solutions are built on known } \\
\text { knowledge and offerings. }\end{array}$ \\
\hline $\begin{array}{c}\text { Step 4: Knowing the } \\
\text { unknowns and recognizing } \\
\text { uncertainties }\end{array}$ & $\begin{array}{l}\text { The time horizon is } \\
\text { unknown and succeeding at } \\
\text { all is uncertain. It is still } \\
\text { necessary to ensure mandate } \\
\text { and resources. } \\
\text { The business units must } \\
\text { embrace risk and accept the } \\
\text { time horizon. }\end{array}$ & $\begin{array}{l}\text { Little or no knowledge of } \\
\text { customers and markets } \\
\text { means that a business case is } \\
\text { only provisory or a best } \\
\text { guess scenario. } \\
\text { Future gains cannot be } \\
\text { predicted prior to engaging } \\
\text { in the innovation process. }\end{array}$ \\
\hline
\end{tabular}




\section{The Catch-22 in Strategizing for Radical Innovation}

\section{Helle Alsted Søndergaard, Mette Proest Knudsen, \& Nicolai Søndergaard Laugesen}

market, or technology first, and defines the level of ambition afterwards.

For example, in the case of Company B (see Box 2 above), if the company starts with container transportation as the product and market focus, the next step then becomes to define if the company wants to be a fast follower, or first mover with radical innovation as the strategic goal. The path defined by starting with a direction clearly has an advantage of knowing the product and market that are subject to innovation. But this path is simultaneously subject to the embedded risk of gravitation towards incremental innovation, as it is more likely to fall into the safety of known products and current market needs.

To avoid this challenge, an alternative path is to start by defining the level of ambition, and thus not let the current product or market heritage and history constrain the level of ambition. Innovation labs are typically established because companies understand the risk of incremental gravitation and want to make a bolder move more freely of constraints. In Company A (see Box 1 above), the starting point was to establish the corporate garage and then by collecting input from customers and business units, let the direction for innovation efforts emerge. In this way, the level of ambition was established before the direction. However, when the starting point is the level of ambition, and the company has a clearly defined strategic objective of radical innovation, it may become difficult for the innovation lab to succeed and survive in the long term, because radical innovation takes time. In contrast, the way for the new lab to prove its value to the rest of the organization is by developing and transferring innovations to the strategic business units in the short term. One solution that tries to bridge these challenges is to combine the level of ambition with an innovation direction that resonates with the corporate strategy, but still has the level of ambition intact, with a dynamic and regularly updated lab roadmap/timeline.

Thus, irrespective if the strategy work starts with an ambition or a direction, both dimensions are critical for formulating a radical innovation strategy that can survive the uncertainties following from radical ambition and still resonate with the overall corporate strategy. The alignment with corporate strategy is the piece in the puzzle that protects radical innovation strategy from side-tracking the innovation or cancelling the efforts when the timeline is long or there are less visible results.

The framework for developing a radical innovation strategy through the two strategic components can be unfolded step-by-step, as presented in Table 1. These steps reflect the challenges described above starting with asking the right questions that are distinct from the questions guiding short term corporate strategy. The next step concerns understanding the gravitational forces towards exploitation rather than only exploration. When the right questions are addressed, and the gravitation is uplifted, then a third step relates to deliberately considering how much alignment between corporate strategy and innovation strategy, and at what cost? Finally, the fourth step towards a strategy for radical innovation is to embrace the uncertainties of the unknowns. We argue that a more deliberate reflection on the unknowns (both known and unknown) ultimately supports the longevity of a company's radical innovation strategy.

Other concerns, beyond the two main challenges, were identified with regard to ensuring progress in strategy implementation. Most importantly, the choices made in each dimension forming a radical innovation strategy can contradict each other, especially if the time horizon is ignored. Some companies work with a sense of urgency and a short timeline. Radical innovation strategies that work with short timelines, however, might contradict their innovation ambition. Similarly, strategies that are born with ambitious revenue targets are difficult to achieve on a short time horizon. Hence, to unfold a radical innovation strategy requires sufficient time and patience to do properly.

Furthermore, limited or no knowledge of future customers and markets following from a change in direction implies that a business case is only provisory and vague. As a business case is an indispensable tool for most companies, the uncertainties following from a change in direction must also tolerate that business cases at this stage can only present images or highly imaginative prospects about future market opportunities.

Finally, the more ambitious the innovation strategy, the more willing business units must be to embrace the risk and uncertainties involved with the radical 


\section{The Catch-22 in Strategizing for Radical Innovation}

\section{Helle Alsted Søndergaard, Mette Proest Knudsen, \& Nicolai Søndergaard Laugesen}

innovation efforts. They will likely not know all that they would prefer to know about the new offerings, regarding what the potentials are, when they can be presented with the new offering, what market needs they may address, etc. Thus, grasping at the unknowns and embracing uncertainties must be a regular part of implementing a strategy for radical innovation.

To sum up the challenges that organizations face when working with radical innovation, we argue that no matter what you do, risks and uncertainties must be faced:

A. If firms create independent/autonomous innovation labs, they risk not being able to re-integrate the work into the ongoing business (alignment challenge).

B. If firms keep their innovation efforts close to the current business, they risk not reaching the intended level of radical innovation (gravitation challenge).

C. Firms have little experience formulating innovation strategy, inadequate vocabulary, and lack familiar processes for discussing the central elements (framework challenge).

As argued earlier, close/tight alignment between corporate and innovation strategies will likely nullify the potential of radical innovation strategy. However, a prerequisite for innovation strategy to work is that choices are made deliberately and not just by coincidence. The choice can be to have a less welldefined strategy formulated, so as to secure autonomy for radical innovation efforts. For example, an x-lab can work with radical innovation without clearly defined end-goals. Some would even argue that working with radical innovation requires that efforts not be tied into specific customer segments or product types.

Even if the degree of alignment is deliberately low, there are still questions to be answered: How much time do we have to develop new innovative products? What is the level of ambition for their development? It is therefore important to acknowledge and deliberately choose a degree of coordination and accept a degree of non-alignment if radical innovation efforts are to have enough freedom to flourish.

\section{References}

Anthony, S.D., Johnson, M.W., \& Sinfield, J.V. 2008. Institutionalizing innovation. MIT Sloan Management Review, 49(2): 45-53.

DOI:

https://doi.org/10.1080/05775132.1963.11469549

Barney, J. 1991. Firm resources and sustained competitive advantage. Journal of Management, 17(1): 99-120.

DOI: https://doi.org/10.1177/014920639101700108

Brown, T., Martin, R. 2015. Design for Action - How to Use Design Thinking to Make Great Things Actually Happen. Harvard Business Review, 93, 9, September 2015: 56-64.

Carnes, C.M., Chirico, F., Hitt, M.A., Huh, D.W., \& Pisano, V. 2017. Resource orchestration for innovation: Structuring and bundling resources in growth-and maturity-stage firms. Long Range Planning, 50(4): 472-486.

DOI: https://doi.org/10.1016/j.lrp.2016.07.003

Chang, Y.C., Chang, H.T., Chi, H.R., Chen, M.H., \& Deng, L.L. 2012. How do established firms improve radical innovation performance? The organizational capabilities view. Technovation, 32(7-8): 441-451.

DOI:

https://doi.org/10.1016/j.technovation.2012.03.001

Demir, F. 2018. A Strategic Management Maturity Model for Innovation. Technology Innovation Management Review, 8(11): 13-21.

DOI: https://doi.org/10.22215/timreview/1196

Dobni, C.B., \& Sand, C. 2018. Strategy shift: Integrating strategy and the firm's capability to innovate. Business Horizons, 61(5): 797-808.

https://doi.org/10.1016/j.bushor.2018.06.002

Hill, C.W., \& Rothaermel, F.T. 2003. The performance of incumbent firms in the face of radical technological innovation. Academy of Management Review, 28(2): 257-274.

DOI: https://doi.org/10.5465/amr.2003.9416161

Kim, W.C., \& Mauborgne, R. 2019. Nondisruptive creation is an alternative path to growth. MIT Sloan Management Review, 60(3): 46-55.

Kuratko, D.F., Covin, J.G., \& Hornsby, J.S. 2014. Why implementing corporate innovation is so difficult. Business Horizons, 57(5): 647-655.

DOI: https://doi.org/10.1016/j.bushor.2014.05.007

Linton, J.D. 2009. De-babelizing the language of innovation. Technovation, 29(11):729-737.

DOI:

https://doi.org/10.1016/j.technovation.2009.04.006

March, J.G. 1991. Exploration and Exploitation in Organizational Leraning. Organization Science, 2(1): 71-87.

DOI: https://doi.org/10.1287/orsc.2.1.71 


\section{The Catch-22 in Strategizing for Radical Innovation}

\section{Helle Alsted Søndergaard, Mette Prøest Knudsen, \& Nicolai Søndergaard Laugesen}

Nagji, B., \& Tuff, G. 2012. Managing Your Innovation Portfolio. Harvard Business Review, (May): 67-74. DOI: https://doi.org/10.1002/9781119175803.ch4

O’Connor, G.C., \& DeMartino, R. 2006. Organizing for Radical Innovation: An exploratory study of the structural aspects of RI management systems in large established firms. Journal of Product Innovation Management, 23(6): 475-497.

DOI: https://doi.org/10.1111/j.15405885.2006.00219.x

Pisano, G.P. 2012. Creating an R\&D Strategy. Harvard Business School (Vol. 95). Working Paper 12.

Pisano, G.P. 2015. You Need an Innovation Strategy. Harvard Business Review, (June): 44-54.

Prange, C., \& Schlegelmilch, B.B. 2018. Managing innovation dilemmas: The cube solution. Business Horizons, 61(2): 309-322.

DOI: https://doi.org/10.1016/j.bushor.2017.11.014

Sainio, L.M., Ritala, P., \& Hurmelinna-Laukkanen, P. 2012. Constituents of radical innovation- exploring the role of strategic orientations and market uncertainty. Technovation, 32(11): 591-599.

DOI:

https://doi.org/10.1016/j.technovation.2012.06.006

Sawhney, M., Wolcott, R.C., \& Arroniz, I. 2006. The 12 different ways for companies to innovate. MIT Sloan Management Review, 47(3): 75-81.

DOI: https://doi.org/10.1109/emr.2007.329139

Sirmon, D.G., Hitt, M.A., Ireland, R.D., \& Gilbert, B.A. 2011. Resource orchestration to create competitive advantage: Breadth, depth, and life cycle effects. Journal of Management, 37(5): 1390-1412.

DOI: https://doi.org/10.1177/0149206310385695

Tidd, J., \& Bessant, J.R. 2018. Managing Innovation: integrated technological, market and organizational change. London, UK: John Wiley \& Sons.

Wessel, M. 2012. Big Companies Can't Innovate Halfway. Retrieved from: https://hbr.org/2012/10/bigcompanies-cant-innovate-halfway

Wilden, R., Hohberger, J., Devinney, T.M., \& Lavie, D. 2018. Revisiting James March (1991): whither exploration and exploitation? Strategic Organization, 16(3): 352-369.

DOI: https://doi.org/10.1177/1476127018765031

\section{About the Authors}

Helle Alsted Søndergaard is Associate professor in Innovation management at the Department of Management, Aarhus University. Her research is focused on aspects of open innovation including employee attitude to external knowledge, employee and user innovation as well as innovation strategy. She has published her work in journals such as Technovation, International Journal of Technology Management, and European Journal of Innovation Management.

Mette Præst Knudsen is Professor of Innovation Management and Director of the Centre for Integrative Innovation Management, Department of Marketing \& Management at the University of Southern Denmark. Her research focuses on innovation management including topics like open innovation and innovation strategy. Further she is concerned with barriers to commercialization of emerging technologies, and how emerging technologies are embedded and grow within innovation eco-systems. Her research has been published in journals such as Journal of Product Innovation Management, Research Policy, Technovation, and Industrial and Corporate Change. She currently serves as Associate Editor for Technology Innovation Management Review, Area Editor for Technovation, and as Senior Advisor for Creativity and Innovation Management Journal.

Nicolai Søndergaard Laugesen is Global Head of Development \& Commercial Excellence at Falck A/S, a global healthcare and ambulance service company. His responsibilities cover both strategies and development of new healthcare solutions.

Citation: Søndergaard, H.A., Knudsen, M.P., \& Laugesen, N.S. 2021. The Catch-22 in Strategizing for Radical Innovation. Technology Innovation Management Review, 11(3): 4-16.

http://doi.org/10.22215/timreview/1425

(cc) BY

Keywords: Innovation strategy, radical innovation, corporate strategy, strategy challenges 